approach that of Hants, the former possessing 176 , the latter r74 of the 242 species found in Hants mainland but absent in one or more of the adjacent floras; the maritime or coast plants being deducted, in order to compare a county not possessing a coast with one possessing such." Regarding the second list the author says :- "We should naturally suppose . . the floras of Surrey and Sussex would again be shown to approach the flora of Hants mainland by this possessing fewer species not found in the latter, and that the floras of Wilts, Berks, and Wight (which by the first list are shown to be most dissimilar from Hants mainland, for Wilts possesses I2I, Berks rog, and Wight only 96 of the 242 species in List No. I) would possess many more species not found on Hants mainland than would Surrey or Sussex; but the reverse is the truth, for these two last named counties are shown by List 2 to possess more species not found on Hants mainland than Wilts, Berks, Wight, or Dorset possess." The author advances an explanation for this apparent contradiction and concludes his "Notes" with "a few words on River Basin Districts," explaining why he "would choose them for showing the geographical distribution of plants in preference to civil or artificial divisions." The value of such notes as these is by no means slight; those before us, we are told by the author, have been published principally in the hope that they may be seen by competent botanists who may have it in their power to communicate additional species or perchance point out errors so that their insertion may be prevented in the flora of Hampshire, which Mr. Townsend hopes soon to publish.

THE additions to the Zoological Society's Gardens during the past week include two Rhesus Monkeys (Macacus erythrous) from India, presented respectively by Dr. Douglas and $\mathrm{Mr}, \mathrm{R}$. C. Bonsfield; a Macaque Monkey (Macacus cynomolgus) from India, presented by Mr. T. Hobbs ; a Bonnet Monkey (Macacus saatiahus) from India, presented by Mrs. Bonamy Dobree; two Arabian Gazelles (Gazella arabica) from Arabia, presented by Capt. W. Bowden Smith, R.N.; a Great Bustard (Otis tarda) from Spain, presented by Mr. George G. Sandeman; two Chinese Tree Pies (Dendrocitta sinensis) from China, presented by Mr. Chas. Rice; a Common Waxbill (Estrelda cinerea) from West Africa, presented by Mr. J. C. Thorowgood; a Sun Bittern (Eurypyga helias) from South America, deposited; a Bosman's Potto (Perodicticus polto) from Sulymah, South-West Coast of Africa, two Crested Colins (Eupyschortyx cristatus) From Mexico, purchased.

\section{THE SANITARY CONGRESS}

1 HE Sanitary Science Congress opened its proceedings 1 at Croydon on Tuesday under the presidency of Dr. B. W. Richardson, F.R.S., who spoke of the success which had attended the work of the Institute. In the evening a general meeting was held in the great public hall to hear the address of the president. As a sort of complement to his previous address in an ideal city, under the title of Hygeia, Dr. Richardson this year, under the title of Salutland, sketched an ideal land, polity, and people. He introduced his fancy sketch as follows:

"On the rgth of July of this year, at the home of the Father of modern Sanitary Progress, who has this moment resigned the chair to me, I met the most illustrious of now living men of science. Our conversation turned on many subjects, all of which were lighted up by the entrancing exposition which always gilds the genius of him to whom I specially refer, Prof. Owen. One subject peculiarly attracted the attention of us who listened to him as he expounded it. We had entered into a discussion on the question of the longevity and the natural duration of life of different classes of animals. With his usual scientific accuracy and industrious research, Owen had on that day estimated, from various data he had collected, the natural term of life of the curious animal, the hippopotamus. He had learned that its term of life was thirty years. He explained to us the mode by which he had arrived at that fact: how into the calculation it had been necesssary to take into account the dentition of the animal ; the stages of development; the natural wearing out of the teeth; the period of gestation; the development of the slieleton into the perfection of a bony fabric, with particular reference to the combination of the epiphyses or loose ends of the bones to the shafts of the bones; and, lastly, the pathological or diseased condition of the dead animal of the species that had arrived at its full longevity, in order to determinesw whether or not there was evidence of cause of death from disease of some particular organ, or whether there was no such evidence, but simply a history of general decay from old age pure and simple.

"We were told that in a hippopotamus which had recently died, and which was known to have just turned thirty years of age, the two sets of teeth had fulfilled their allotted duty; that the bones of the skeleton were duly consolidated; and, that the organs of the body were equally degenerated; so that death had occurred, not from failure of any particular organ, but from failure of the organic parts altogether. In a sentence, the animal had died a natural death, and the constant of the term of life of it and its family was set down at thirty years, a constant to which all the facts that could be collated in respect to this species of animal definitely pointed.

"From this line of facts in respect to one type of animal life we were led to others, and the rrule, Iaid down by the distin. guished Flourens, by which the determination of natural old age is calculated on the basis of perfected maturity, was brought under review. The skeleton is perfected when the epiphyses or loose terminal parts of long bones are firmly united with the shaft of the bone. When the date of such perfection of development is known in the mammalian class of animals, the simple process of multiplying the age at that date by five, gives the natural anatomical life of the animal. The elephant came before us as an example. A young elephant, whose history has been related in the Philosophical Transactions, died at the age of thirty years. At that age the epiphyses of its bones were not completely united with the shafts. It was nearly but not quite matured. Multiply thirty by five, and one hundred and fifty years stand as the natural estimate of the life of the elephant, so that really an elephant might exist which had itself carried all the Governors-General of our Indian Empire. Moving from this animal of long life, we turned to the camel, to find full maturity at eight years, full life at forty. We turned to the horse, to find full maturity at five years, full life at twenty* five. We turned to the lion and the ox, to find full maturity at four years, full life at twenty. We turned to the dog to find, full maturity at two years of age, full life at ten. We turned to the cat, to find full maturity at eighteen months, full life 'at seven and a half years. We turned to the rabbit, to find full maturity at one year, full life at five.

"From these contemplations our minds very naturally reverted to the animal, man, to the members of the human family. Man, we learned, follows the same rule as the rest of living beings. Judged by the same test, his full maturity and full age may be calculated with equal precision. His maturity, -perhaps not quite the full maturity, -is twenty years. His full age, therefore, is one hundred years. This is the anatomical estimate of human life, the surest and by far the best of all that can be supplied, since it defines a law irrespective of and overriding all those accidental circumstances of social and physical storm and strife, which may interfere, and indeed do interfere, with ievery estimate based on the career of life itself, as it is shown in the ephemera by and through whom it is phenomenally demonstrated.

"This lesson, told with singular felicity of language from two masters of science,-for Owen never forgot Flourens, - struck $\mathrm{Mr}$. Chadwick and myself with singular force. On a surer basis than we ever trod, it corroborated a view we had ourselves pro. mulgated from entirely different stand-points; and it further corroborated a similar view which had been advanced by our eminent friend, Dr. William Farr. We were led, in a word, once again, to the inevitable conclusion that man, even in this stage of his probation on the planet, is naturally destined to walk upon it, endowed with sensibilities of life and intelligence, for a period of one hundred years, and that until he realises this destiny practically, he is in value of physical life actually degraded far below his earth.mates, whom he designates the brute creation, and over whom he presumes to exercise his, to 
them, almighty will. The constant of human life is naturally

one hundred years. referred to, something never to be forgotten. The constant was refere remains. Because before us in all its the fne hundred years, it is not an essential that the fulness of age is one hundred the advent of that fulness. To death shall immediately crown natural life there is a boundary. certain parts of the schity of development has its boundary of twenty The period of maty body, as Flourens says, ceases to grow; but if years; when the ordinary sense of the term, to grow it does not cease to increase; its nutrition improves and perfects for twenty cease to more at least, and then only has reached its completed yhysical condition. It should never from that period gain in weight, and for a long time it should not lose. It goes on now through a third period, which Flourens admirably calls the period of invigoration, during which all its parts become firmer, all its functions more certain, all its organization more perfect; and this period covers thirty years. At seventy old age begins; the first old age, in which naturally the fruits of wisdom are most bountifully developed, and which lasts from fifteen years to twenty, to mellow down to a period of ripe old age, commencing at eighty-five years and lasting fifteen years more, i.e., until the constant is attained.

"And yet there need not now be death; for though, as Lord Bacon has said, old men are like ruined towers, and though, as Flourens has quoted, youths live in a double sense, with forces in reserve and forces in action, vires in posse et vires in actut, the radical forces and acting forces of Barthez, while old men live only on the forces in action, 'vires in actu,' possessing no reserve, it is wonderful how the forces in action will continue after the reserve is withdrawn. This kind of half-life has continued unquestionably many years beyond the fulness of age, both in man and lower animals, and to give it twenty years beyond the natural hundred is to be just without being in any extreme sense generous.

"In this anatomical reading iof human life" we see the growth, the increase, the invigoration, and the solidification, of the body: we see the life with its reserve on its two threads; the life without reserve on its one thread; and, finally, - the force in action being withdrawn--the life ceasing, and the earth, proclaiming her mastery, diagging the actor as unconsciously to herself at death, as he was unconsciously projected into the world at birth.

"All through this presentation of natural fact, moreover, there runs another physical truth. Death is centripetal action. Those two birds on the wing which up to heaven's gate sing, are physically filled, like the gyroscope, with the vires in posse et vires in actu, powers in reserve and powers in action. Yon wanton sportsman liberates a ball which pierces one bird, and the earth claims its prey. The living gyroscope falls. The fellow bird escapes. In time, it fails to rise to the same height, its force in reserve being withdrawn, but its force in action remains, and it lives on. At last, some trifling extra call upon it is final, and the triumphing earth brings it down to itself. That first bird fell from an interference with its life while yet it had its two powers; that second bird fell from failure of powers at different periods, but from the same inevitable, always present cause, the attraction of the earth.

"The same is true of men also. What we call death is gravitation: what we call disease, is some accidental shot inflicted, it may be, while still the self-resistance to gravitation is in operation: what we call natural death is the gradual overweighting, at different periods, of the natural powers, reserve and acting, by the persistent force that bears us down. We cease to grow at a certain stage of our life, because of the resistance of this downward force: we cease to increase in size from the same cause: we consolidate in structure from the same cause: we bend in old age from the same cause: and we die from the same cause. Every step has practically been a death from the same cause.

"As these facts appear, we are inclined to ask, How many of all men and women projected into life and charged with the reserve and acting forces, - how many die with these forces intact up to the time of death, and how many with the acting force alone in operation? How many, if I may use the simile, die on the wing, fall headlong to the earth, shot by some wanton shaft that need never have been discharged? How many sink naturally to the earth from her final and gentle embrace?
"The answer to this question appals the mind. The answer rings out:-Man reckless of life! every lower animal you do not immolate beats you in this! Man! civilized as you are proud to say, you have never yet given life a chance! Man of reserve and action, you die on the wing more certainly than the birds of the air on which you practise your fatal sports! You die within the first part of the second third of your natural lives. Let the elephant die at sixty, the camel at sixteen, the horse at ten, the dog at four, the cat at three years, and the rabbit at two years, and they will then match you in the value of life you train yourself to possess. Man, endowed with knowledge of science, who can divide the year into seasons, and history into centuries and eras; who can calculate the courses of the planets and predict their crossings and shadows; weigh the earth, as in a balance, and predicate storms and tempests, you have yet to learn that, with the precision that regulates all these things, your own life is meted out, - that such a childhood means such an adolescence, such an adolescence such a maturity, such a: maturity such a decline, and such a decline such a periodof death.

Nay more; man so endowed does sometimes see by adventure, as it were, the whole law fulfilled without his studying for it or expecting it. Some individual lives the whole natural period of life, exceptionally, as an elephant, a horse, a lion, a dog, a cat lives it ordinarily, and thus by adventure, proves the truth of the law which has been laid down. The event, perfectly commonplace in the case of a lower animal, -..-a dog that lives to ten,-is a perfect marvel when it happens to a man who lives to a hundred years, the equal term. To see a centenarian we travel miles and miles, and discuss the time of his birth with keenest criticism, so truly unnatural is the state of things under which human existence at present is unfulfilled.

"The question arises, How long is this condition of affairs to last? No more vital question stands for solution at the bar of civilisation.

"The day, in fact, has now arrived, when the cultivation of life by the cultivated of mankind is the primary art for the continuance of the cultivated. If the civilised world would continue in the ascendant, it must learn to live. An average life of forty. one and under favourable circumstances of forty-nine years, with a world of disease and death up to that period, and a scattered struggle of the fittest for an exceptional existence into ripe old age, camnot maintain the relative efficiency of any nation, except in a world universally and equally bad. Ingenuity itself is bounded by life; device by faculty for devising. Weapons of precision give us victory over savages. Is that success? Weapons are made, not begotten, and savage tribes, fierce for contest and unscrupulous, may readily learn to apply what the civilised man has devised, and in repetition of history, make easy. work of the short-lived civilised.

"We Sanitarians are forced by our studies to recognise these truths. We exist, if we exist for any great purpose at all, to protest against the casting away of nearly two-third; of the life that is meted out for civilised men. We exist to protest that it is not a scientific civilisation which can permit such reckless waste of the gift that stands above all values and qualities; and our protest is the more earnest as we detect that the waste which we observe, is actually not at the time of life after the prime has been reached, but is most destructive in the very budding of life, and continues at the intermediate stages between the period of budding and the prime.

"To speak in plain terms, - and if ever plain terms were demanded, they are demanded now,--the world in this matter of life and death has, by daily observation of the phenomena, got into the habit of looking on wrong as right, and on what is practically suicidal death as death that is natural. It is a strange fatuity. If we were, for a short time, to see the lower domestic creatures under the same curse; if we were to witness horses enjoying ten, dogs four, and cats three years, as an average duration of their lives, we should think a persistent murrain had come upon them, and that, in relation to these useful domestic animals, the whole course of life had undergone a deteriorative change. Yet that is what, in effect, we are observing amongst our own kind, so that the Sanitarian in despair may exclaim: ' Oh that man were as wise as the horses and dogs, that he might have the bounty of life which the Allwise has awarded to him as the natural bounty, extended and beautified and exalted by the intelligence with which he is endowed above the beasts.'

"I press the question. Why should we, of all animals, perish as we do in the first part of the second third of ous 
natural career? Why are all the doctors of the human species, with their flowing knowledge and consummate skill, to carry out cure? Why are they so set at naught, that the lower animals, who have no advantage of their services, have a higher vital possession than man at their command?

"'The answer is told in a few words. It is that we have never as a community let ourselves study the question; have never, in truth, looked at the facts, plainly as they st and forth.

"And now comes another question-IKnowing the facts knowing what is the natural term of human life, can mankind learn to attain that term? Can man learn to live his hundred years, with a prospective chance of extension to a fifth of a century more? Instead of being cut down at the moment when he has filled his intelligent mind with the learning of his time, and when his knowledge is just becoming transmutable into wisdom, can he go on, an intellectual being, brought to the highest pitch of usefulness? Can he go on to the full term of his natural and prospective course?

"I do not dare answer that question on my own account, because it is answered for me. He who gave the life has answered the question. He has written it for us in unmistak able lanouage. $\mathrm{He}$ has shown all of us who can read $\mathrm{His}$ natural designs, that it is one of them that man may live the term if he will. Free-will making a man a free agent, is all that is set above the natural law, and free-will is natural law too, government by intelligence which is as natural, and is as freely supplied.

"How, then, shall civilised man live, that the natural term may be found?"

Dr. Richardson then proceeded to sketch his ideal Salutland, located somewhere to the extreme south of Mr. Hepworth Dixon's "New America," the time being the middle of the twenty-first century. He depicted its polity, its social and domestic life, its people, its work, its sanitary arrangements.

\section{UNIVERSITY AND EDUCATIONAL INTELLIGENCE}

Tul ninth session of the Newcastle College of Science was opened on the $3^{\text {th }}$ inst., when very satisfactory reports of the progress of the institute were made. Prof. Lebour delivered the inaugural address on Some Aspects of Geology. Interesting and genial speeches were given by Lord Ravenworth, the Dean of Durham, and others.

From the Calendar of Anderson's College, Glasgow, we see that a very complete education can be obtained at that institution in science and medicine, the fees being unusually low. The Calendar has an interesting sketch of the life of John Anderson, F.R.S., the founder of the college, as also of the institution itself.

M. FERRY, the Minister for Public Instruction, having arrived in Paris, has visited the Observatory and the School of Medicine, where important works are being carried out. One of the peculiarities of the new buildings will be the large number of dissection rooms. More than a hundred tables will be prepared for dissections, so that every student in medicine will be enabled to take part in épreuves pratiques, which vill be an essential part of the education of medical students.

THe new college so liberally endowed by Mr. Mark Firth, at Sheffield, was opened on Monday by Prince Leopold. The endowment, it is expected, will soon reach $25,000 \%$, and the institution is mainly intended for carrying out the University extension scheme, which has been remarkably successful in Sheffield. The building seems to be altogether satisfactory, and, we are glad to see, contains provisions for experimental instruction in chemistry and physics. Prince Leopold insisted on the great benefits which must acciue to the working classes from the establishment of such an institution.

Prof. MaX Múller, on Monday night, delivered the president's inaugural address on the opening of the winter session of the Birmingham and Midland Institute. His German and Italian friends, he said, while recognising that full political liberty reigned here, thought there was little intellectual freedom, and that, however it might be in London and a few other large cities, the Universities-the nurseries of thought and learning-were fettered by the medixval spirit of monastic institutions and the principles of scholastic philosophy, which contrasted ill with the freshness and freedom of Continental Universities.

\section{SCIENTIFIC SERIALS}

The Quarterly Fournal of Microscopical Science, October. -W. B. Scott and H. F. Osborne, On some points in the early development of the common newt, with pl. 20 and 21 E. Ray Lankester, On the structure of Haliphysema Tuma. nowiczii, with pl. 22, generally confirming the facts recorded by $\mathrm{Mr}$. Saville Kent, and failing to observe the collar-bearing flagellate cells described by Haeckel. Prof. Lankester shows the structure to be however not quite so simple as that which is supposed to characterise the body substance of such Foraminifers as the Lituolida.-E. Ray Lankester, On a new genus and species of Gymnomyxa (Lethamaba discuss) p1. 23.-1H. Gibbes, On the structure of the vertebrate spermatozoon, pl. 24. - Index to volume xix., N.S.

The American Naturalist, September.-Brazilian corals and coral reefs, by $R$. Rathbun. - The formation of Cape Cod (conclucled), by W. Upham. - The hillocks or mound-formations of San Diego, California, by Dr. G. W. Barnes. - Insect powder, by W. Saunders.--Recent literature ; General notes ; Scientific news; Proceedings of Scientific Societies; Selected articles.

Fournal de Physique, September.--M. Bouty here describes some mechanical phenomena which accompany electrolysis; his paper treats (I) of pressures exerted by galvanic deposits, (2) of the action of heat on metallised thermometers, and (3) of peculiarities of nickel.-M. Sebert gives an account of the accelerograph of $M$. Marcel Deprez, in its most recent form; the apparatus is for measuring pressures developed by gases from powder (which are caused to act on a piston). - There are also notices of M. Deprez's magneto-electric machine (in which a Siemens armature is arranged to work between the branches of a horse-shoe magnet, being about equal to these in length), and a new form of electroscope, by M. Guerout.

Asiatic Society of Bengal, vol, 47, No. 223, N.S., April 6.Description of Thaumantis loutisa, pl. 12, from Upper Tenasserim, by J. Wood Mason.--On a great snow-fall in Kashmir, by R. Lydekker.-Physiographical notes, \&c., on Tanjore, by Lieut.. Colonel B. R. Branfell.-On the proper relative sectional areas for copper and iron lighting rods, by R. S. Brough, Description of a new Homopteron (Cosmoscarta masoni), by W. L. Distant.-On the Indian species of the genus Erinaceus, by Prof. Dr. Anderson, with 4 plates.-On a supposed new hedgehog (Erinaceus niger) from Muscat Arabia, with"a plate.-On Arvicola indica, Gray, and its relations to the sub-genus Nesokia, with a description of the species of Nesokia (pl, I3 and 14), by Prof. Dr. Anderson; Index to Volume.

Morphologisches Fahrbuch, Bd. 5, Heft 2.-A. Pansch, Memoir on the morthology of the cerebral hemispheres, in mammalia, pl. I4 and 15.-H. Strasser, On the development of the $\operatorname{limb}$ cartilages in Salamanders and Tritons, pl. 16-19.-G. v. Koch, Notes on the skeleton of corals, p1. 20,-M. Fiirbringer, On the question of the formation of nerve plexi, pl. 21, 22.-C. Semper, Reply to Prof. Fürbringer's article "On Homology." - Prof. Furrbringer, On the chief points alluded to in Prof. Semper's reply. - Notices.

Zeitschrift für wissenschaftliche Zoologie, Bd. 32, Heft 4, August.-On the worm fauna of Madeira, by Prof. Langer hans, pl. 3r-33. Describes a large number of new genera and species.-Researches into the structure and development of the 'Sponges, seventh notice: The family of the Spongidx, by Prof. F. E. Schulze, pl. 34, 38.-7yphloscolex miilliri, W. Busch, being a supplement to notes on the pelagic annelids of the coasts of the Canary Islands, by Prof. R. Gree, pl. 39. -On the oral skeleton of Asterids and Ophiurids, by Dr. H. Lidwig.

\section{SOCIETIES AND ACADEMIES LONDON}

Entomological Society.-October I.-Sir John Lubbock, Bart, F.R.S., president, in the chair.-The President alluded to the loss which the Society had sustained by the death of Mr. Wm. Wilson Saunders, F.R.S., and a former President of the Entomological Society, and announced that the council had accepted the responsibility of awarding two prizes offered by Lord Walsingham and other gentlemen for the best and most complete life-his. 